\section{Root and Rhizome Growth of Kentucky Bluegrass Following Application of Pendimethalin}

\author{
R.J. Cooper, P.C. Bhowmik, and L.A. Spokas \\ Department of Plant and Soil Sciences, University of Massachusetts, \\ Amherst, MA 01003
}

Additional index words. Poa pratensis, preemergence, herbicide, turfgrass

\begin{abstract}
Field experiments were conducted to determine the response of five widely used Kentucky bluegrass (Poa pratensis L.) cultivars (Adelphi, Baron, Bensun, Merion, and Touchdown) to preemergence applications of the herbicide pendimethalin. Pendimethalin applied during 2 years at 1.7 or $3.4 \mathrm{~kg} \cdot \mathrm{ha}^{-1}$ (a.i.) controlled smooth crabgrass [Digitaria ischaemum (Schreb. ex Schweig.) Schreb. ex Muhl.] effectively without injury to turf. Pendimethalin at $3.4 \mathrm{~kg} \cdot \mathrm{ha}^{-1}$ resulted in a short-term suppression of root growth immediately following application in the first year of the study. The reduction was transitory and subsequent rooting and rhizome growth were unaffected by pendimethalin. Cultivar $x$ pendimethalin level interactions were not significant during the study. Thus, the herbicide appears to be a safe, effective preemergence material for crabgrass control in Kentucky bluegrass turf. Chemical name used: N-(1-ethylpropyl)-3,4-dimethyl-2,6 -dinitrobenzenamine (pendimethalin).
\end{abstract}

Preemergence herbicides are applied routinely to turfgrass for control of annual grassy weeds. Although the benefits of annual grass control are well known, concerns exist as to whether preemergence herbicides may adversely affect the growth of desirable turf species. Many of the commonly used preemergence herbicides have been shown to have inhibitory effects on the growth of certain cool-season turfgrasses (Bhowmik, 1988; Christians, 1984 Shearman et al., 1979). In addition, cultivars within a particular species may vary in their ability to tolerate preemergence herbicides without injury (Christians, 1982; Dernoeden et al., 1988; Hurto and Turgeon, 1979; Shearman et al., 1979).

Pendimethalin is used widely for preemergence control of annual grassy weeds in turf. Although its efficacy and lack of phytotoxicity have been demonstrated (Bhowmik, 1988; Demoeden et al., 1988; Watschke, 1983), research results concerning its effects on turfgrass rooting and rhizome growth have indicated potential for injury. Jagschitz (1986) evaluated pendimethalin applied to immature (7.5-month-old) Kentucky bluegrass sod and noted that applications of 1.7 and $3.4 \mathrm{~kg} \cdot \mathrm{ha}^{-1}$ inhibited tillering for up to 22 weeks after treatment (WAT). In addition, sod strength was significantly reduced 22 WAT by pendimethalin applied at $3.4 \mathrm{~kg} \cdot \mathrm{ha}^{-1}$. In experiments conducted on both seedling and mature Kentucky bluegrass, Reicher and Christians

\footnotetext{
Received for publication 9 Nov. 1988. Contribution from the Massachusetts Agr. Expt. Sta., Amherst, Journal Article no. 2910. This work was supported in part by state and Hatch Act funds (Project 526) allocated to the Massachusetts Agr. Expt. Sta. The cost of publishing this paper was defrayed in part by the payment of page charges. Under postal regulations, this paper therefore must be hereby marked advertisement solely to indicate this fact.
}

$(1986,1988)$ reported that recommended rates ( 1.7 to $3.4 \mathrm{~kg} \cdot \mathrm{ha}^{-1}$ ) of pendimethalin significantly inhibited rooting. Dernoeden et al. (1988) found that pendimethalin at 3.4 kg-ha' restricted perennial ryegrass (Lolium perenne L.) rooting to $54 \%$ and $22 \%$ of untreated turf at 4 and 15 WAT, respectively. Despite significantly reduced rooting, decreased visual quality was not observed.

Since annual grassy weed problems are often greatest in low-density, poor-quality turf, it is important that preemergence herbicides not impair the growth of desirable grasses into areas previously occupied by weeds. Published work indicates that the potential may exist for inhibition of turfgrass growth following pendimethalin application. The purpose of this study was to evaluate the rooting, rhizome production, and quality of five widely used cultivars of Kentucky bluegrass in response to annual applications of pendimethalin.

Pendimethalin (60 WDG) was applied on 3 May 1986 and 16 Apr. 1987 at 0, 1.7, and $3.4 \mathrm{~kg}$ a.i./ha to $0.9 \times 1.8-\mathrm{m}$ field plots of 5-year-old 'Adelphi', 'Baron', 'Bensun', 'Merion', and 'Touchdown' Kentucky bluegrass growing on a Hadley silt loam soil (coarse, silty, mixed, nonacid, mesic Typic mean of 15 observations.

${ }^{2}$ Treatments applied 3 May 1986 and 16 Apr. 1987.

${ }^{y}$ Sampled 15 Apr., 1 day before treatment.

, *Nonsignificant or significant at $P=0.05$, respectively.
Udifluvent). These cultivars, with the exception of 'Merion', were chosen because of their widespread use in seed and sod mixtures. 'Merion', although not currently recommended for new seedings or sod, remains a common component of many existing turf areas. The experimental design was a randomized complete-block with three replications. Treatments were applied using a $\mathrm{CO}_{2}$ powered backpack sprayer at $207 \mathrm{kPa}$ of pressure delivering 1390 liters $\cdot \mathrm{ha}^{-1}$. All turf (field plots and plugs used for rooting and rhizome determinations) was maintained at a mowing height of $5 \mathrm{~cm}$, with irrigation applied as necessary to prevent drought stress. Nitrogen was applied at $49 \mathrm{~kg} \cdot \mathrm{ha}^{-1}$ during May and September of each year. The fungicides tetrachloroisophthalonitrile (chlorothalonil) and 3-(3,5 -dichlorophenyl)-N-(1methylethyl)-2,4-dioxo-1-imidazolidinecarboxamide (iprodione) were applied on a curative basis at recommended rates for control of dollar spot (Sclerotinia homoeocarpa).

Turfgrass quality and crabgrass control. Visual ratings of quality were made several times during each growing season using a scale of 1 to 9 , where $1=$ brown, lowquality turf; $6=$ acceptable; and $9=$ dark green, high-quality turf. Smooth crabgrass control was assessed visually on field plots using a scale of $\mathrm{O}$ to 100 , with $\mathrm{O}$ representing no crabgrass and 100 indicating complete crabgrass ground coverage. Percent control was expressed as a percentage of mean crabgrass cover in untreated plots. Crabgrass density in turfgrass plugs used for root and rhizome study was determined twice during 1986 and once during 1987 and was expressed as plants/dm².

Root and rhizome development. On 6 May 1986, 10.8-cm-diameter $\times 2.5$-cm-deep plugs were removed from each pendimethalin level/cultivar plot and transplanted into a sand bed in the field using three replications in a split-plot design with cultivars as main plots and pendimethalin levels as subplots. Sufficient plugs were transplanted to allow for the harvest and destructive sampling of separate plugs on each harvest date. To evaluate rooting depth and mass, as well as rhizome production, length, and mass, plugs were harvested 30, 61, 131, and 209 days after treatment (DAT) during 1986.

Harvesting consisted of excavating each plug, along with associated sand within a 15$\mathrm{cm}$ radius, to a depth of $25 \mathrm{~cm}$. Sand was

Table 1. Pendimethalin influence on Kentucky bluegrass maximum root length. Values represent the

\begin{tabular}{|c|c|c|c|c|c|c|c|}
\hline \multirow{4}{*}{$\begin{array}{l}\text { Pendimethalin } \\
\left(\mathrm{kg} \cdot \mathrm{ha}^{-1}\right)\end{array}$} & \multicolumn{7}{|c|}{ Maximum root length $(\mathrm{cm})$} \\
\hline & \multicolumn{4}{|c|}{1986} & \multicolumn{3}{|c|}{1987} \\
\hline & \multicolumn{7}{|c|}{ Days after treatment ${ }^{z}$} \\
\hline & 30 & 61 & 131 & 209 & $0^{y}$ & 40 & 110 \\
\hline 0 & 4.4 & 7.1 & 6.0 & 5.8 & 9.9 & 12.8 & 10.3 \\
\hline 1.7 & 3.6 & 7.6 & 6.0 & 5.9 & 8.4 & 12.2 & 9.7 \\
\hline 3.4 & 2.7 & 6.8 & 6.8 & 6.6 & 9.7 & 11.5 & 9.7 \\
\hline$F$ test & $*$ & NS & NS & NS & NS & NS & NS \\
\hline
\end{tabular}


Table 2. Rhizome growth of Kentucky bluegrass cultivars during 1986.

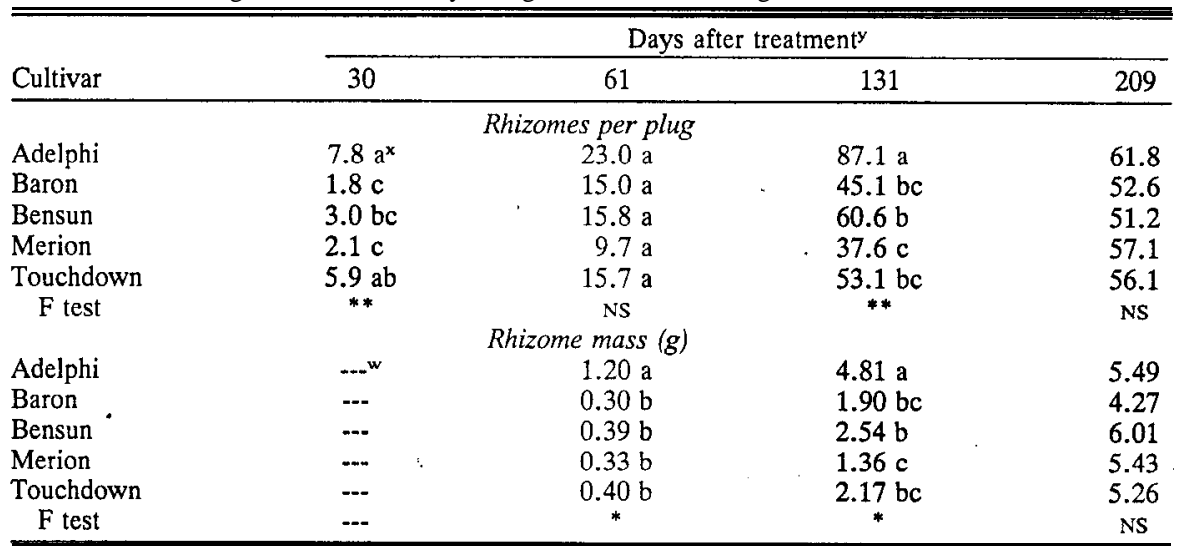

${ }^{2}$ Values represent an average of nine observations across all pendimethalin levels (cultivar-pendimethalin level interaction is NS).

Treatments applied 3 May 1986.

${ }^{x}$ Mean separation within columns by Duncan's multiple range test, $\mathrm{P}=0.05$.

"Samples insufficient for analysis.

Ns, ***Nonsignificant or significant at $P=0.05$ or 0.01 , respectively.

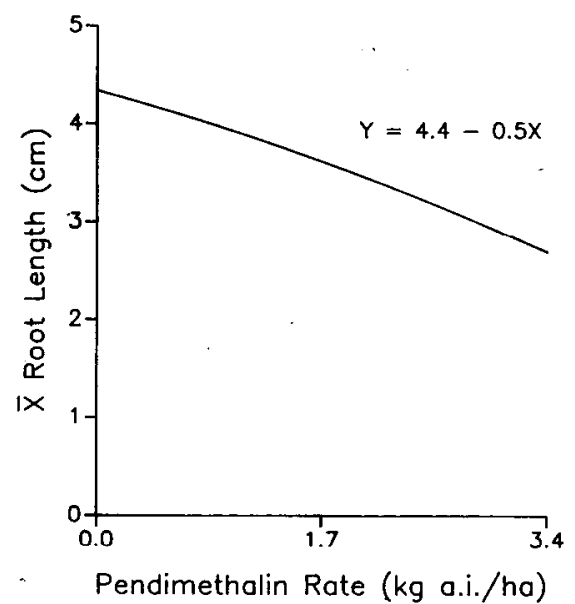

Fig. 1. Mean maximum root length of Kentucky bluegrass turf 30 days after pendimethalin application, 1986. The plot is a significant $(P=$ $0.05)$ linear regression. Values represent the mean of 15 observations.

carefully washed from the roots before determining mean maximum root length. Roots were then clipped from each plug to determine root mass. Root mass represents the difference between oven dry weight $(70 \mathrm{C}$ for $48 \mathrm{hr}$ ) and ash weight (600C for $24 \mathrm{hr}$ ). Rhizome production was determined by counting the number of rhizomes that originated from a given turfgrass plug and secondary rhizomes branching from those primary rhizomes. Both types were measured to determine average length and were then ovendried at $70 \mathrm{C}$ for $48 \mathrm{hr}$ to determine rhizome mass per plug.

To assess the effect of a second annual application on rooting and rhizome development, pendimethalin was reapplied, using the procedure previously described, on 16 Apr. 1987 to the remaining Kentucky bluegrass plugs growing in the sand bed. During 1987, root growth and rhizome development were evaluated 1 day before application and at 40 and 110 DAT.
Statistical analysis. AH values were subjected to an analysis of variance (ANOVA) using the Statistical Analysis System (SAS, 1982). Significant pendimethalin application level effects were evaluated using stepwise polynomial regression (SAS, 1982). Dunmean separation when the ANOVA F test indicated that cultivar effects were significant.

Turfgrass quality and crabgrass control. During 1986 and 1987, pendimethalin applied at 1.7 and $3.4 \mathrm{~kg} \cdot \mathrm{ha}^{-1}$ provided excellent, season-long control of smooth crabgrass (97\% and $99 \%$, respectively) in field plots of all Kentucky bluegrass cultivars. The lack of crabgrass encroachment in pendimethalin-treated turf plugs maintained for rooting and rhizome evaluation confirms and 6.4 crabgrass plants/dm ${ }^{2}$ during 1986 and 1987, respectively. Crabgrass encroachment in response to pendimethalin at either level averaged less than one plant/dm in 1986 and none in 1987. As in the field plot evaluation, the 3.4-kg application did not provide significantly better control than pendimethalin applied at $1.7 \mathrm{~kg} \cdot \mathrm{ha}^{-1}$.

Kentucky bluegrass field plots showed no injury from pendimethlin application at either level throughout the study. Visual quality, averaged for all cultivars, in response to pendimethalin applied at $0,1.7$, or $3.4 \mathrm{~kg} \cdot \mathrm{ha}$ rated 7.6, 7.5, and 7.7 during 1986 and 6.8, 6.8 , and 6.9 during 1987 . The cultivar $\times$ pendimethalin level interaction for turfgrass quality was not significant at any time during the study, indicating a lack of cultivar-specific sensitivity to pendimethalin.

Root and rhizome development: pendimethalin effects. Pendimethalin at either level had no effect on mean maximum root length throughout the study, except when evaluated 30 DAT in 1986 (Table 1). The relationship of maximum root length to pendimethalin level 30 DAT during 1986 was linear and is described by the equation $\mathrm{Y}=4.4-0.5(\mathrm{X})$ can's multiple range test was employed far effective control. Untreated turf averaged 4.0
(Fig. 1). Inhibition of root length 30 DAT (1986) was transitory and was not evident when plants were sampled 61 DAT in 1986. In addition, restricted root length was not observed in response to a repeat application of pendimethalin in 1987.

The short-term inhibition of root length during 1986, as well as the lack of restricted rooting following 1987 application to transplanted plugs, might be explained by the nature of dinitroaniline herbicide activity, which is characterized by low water volubility and a mode of action involving inhibition of both cell division and elongation of lateral roots (Ashton and Crafts, 1981);

In 1986, newly transplanted plugs had root systems predominantly within the upper 2.5 $\mathrm{cm}$ of soil, where they likely would be subject to the inhibitory effects of pendimethalin. As the 1986 season progressed, and by the time of reapplication during Spring 1987, the plugs had developed notably longer roots (Table 1). Thus, given the low water volubility of pendimethalin, it is plausible that much of the root system was then below the herbicide layer and unaffected by the application.

This reasoning may explain other research nating only a short-term inhibition of Kentucky bluegrass rooting following pendimethalin application. Reicher and Christians (1986) reported a decrease in root mass 50 days after application of pendimethalin at 1.7 or $3.4 \mathrm{~kg} \cdot \mathrm{ha}^{-1}$ on mature, low-maintenance Kentucky bluegrass, while no inhibition was evident 100 DAT. Bingham et al. (1988) also reported inhibited rooting of Kentucky bluegrass (42 DAT) in response to pendimethalin applied at $3.4 \mathrm{~kg} \cdot \mathrm{ha}^{-1}$ in Virginia.

Since the $3.4-\mathrm{kg} \cdot \mathrm{ha}^{-1}$ level provided no improvement in crabgrass control over 1.7 $\mathrm{kg} \cdot \mathrm{ha}^{-1}$ in this study, no justification exists for applying the higher level for crabgrass control in the northeastern United States. Thus, the turf would not be subject to the significant decline in root length observed with the $3.4 \mathrm{~kg} \cdot \mathrm{ha}^{-1}$ application.

Throughout the study, root mass remained unaffected by pendimethalin application at either level. Root mass during 1986 averaged across all treatments ranged from 0.34 g/plug 30 DAT to $1.3 \mathrm{~g} / \mathrm{plug} 209$ DAT. During 1987, average root mass increased from $2.2 \mathrm{~g} / \mathrm{plug} 1$ day before treatment to $2.7 \mathrm{~g} /$ plug 110 DAT.

Rhizome production per transplanted plug, as well as rhizome length and mass, were not affected by pendimethalin application during the study. During 1986, rhizome production averaged across all treatments reached a maximum of 56 rhizomes/plug 209 DAT. Rhizome length and mass averaged for all cultivars increased to $13.2 \mathrm{~cm}$ and $5.5 \mathrm{~g} /$ plug, respectively, as determined 209 DAT. Rhizome growth during 1987 continued to be vigorous and unaffected by pendimethalin application.

Cultivar effects. Throughout the study, the cultivar $\times$ pendimethalin level interaction remained nonsignificant for all measures of root and rhizome growth, indicating no cultivar-specific response to pendimethalin. Mean 
maximum root length did not vary significantly among cultivars during either year, and increased from $3.7 \mathrm{~cm} 30$ DAT in 1986 to $9.9 \mathrm{~cm} 110$ DAT in 1987 . Root mass was similar for all cultivars, ranging from an average low of $0.35 \mathrm{~g} / \mathrm{plug} 30$ DAT in 1986 to $3.44 \mathrm{~g} / \mathrm{plug} 40$ DAT in 1987. Unlike root production, differences were noted in the number and mass of rhizomes produced by Kentucky bluegrass cultivars during 1986 (Table 2). In particular 'Adelphi' produced more rhizomes and a greater mass than other cultivars on two of the first three observations. Although 'Adelphi' exhibited superior rhizome production capacity through the 131 DAT (1986) observation date, rhizome production and growth of other cultivars increased with time, so that no significant differences among cultivars were observed 209 DAT in 1986 or during 1987 (data not presented). Our results indicate that pendimethalin can be used on these cultivars without concern for foliar injury or restricted root and rhizome production. Concurrent work by Bhowmik (1988) revealed that pendimethalin applied to 'Baron' Kentucky bluegrass at 1.7 or $3.4 \mathrm{~kg} \cdot \mathrm{ha}^{-1}$ did not inhibit either rhizome growth or tiller formation when measured 4, 8, and 12 WAT. Although some root length inhibition occurred immediately after the 1986 pendimethalin application in this study, it was short-lived and did not affect quality or subsequent root growth.

\section{Literature Cited}

Ashton, F.M. and A.S. Crafts. 1981. Mode of action of herbicides. 2nd ed. Wiley, New York.

Bhowmik, P.C. 1988. Response of Kentucky bluegrass to dinitroaniline herbicides. Proc. Northeast. Weed Sci. Soc. 42:189.

Bingham, S. W., W.J. Chism, and R.L. Shaver. 1988. Effects of prodiamine and pendimethalin on root development of turfgrasses. Proc. South. Weed Sci. Soc. 41:120.

Christians, N.E. 1982. Preemergence herbicide effects on four Kentucky bluegrass cultivars. HortScience 17:911-912.

Demoeden, P. H., D.B. Davis, and J.D. Fry. 1988 Rooting and cover of three turf species as influenced by preemergence herbicides. Proc. Northeast. Weed Sci. Soc. 42:169-173.

Hurto, K.A. and A.J. Turgeon. 1979. Influence of thatch on preemergence herbicide in Kentucky bluegrass (Poa pratensis) turf. Weed Sci. 27:141-146.

Jagschitz, J.A. 1986. Herbicide effects on development and rooting of Kentucky bluegrass sod. Proc. Northeast. Weed Sci. Soc. 40:280-281.

Reicher, Z.J. and N.E. Christians. 1986. Effect of preemergence herbicides on rooting of $\mathrm{Poa}$ pratensis. Amer. Soc. Agron. Madison, Wis. Agron. Abstr. p. 137.

Reicher, Z.J. and N.E. Christians. 1988. Herbicide effects on rooting of Kentucky bluegrass. Amer. Soc. Agron. Madison, Wis. Agron. Abstr. p. 155.

SAS Institute, Inc. 1982. SAS user's guide. 1982 ed. SAS Institute, Inc., Cary, N.C.

Sheannan, R. C., E.J. Kinbacher, and D.H. Steinegger. 1979. Herbicide effects on sod transplant rooting of three Kentucky bluegrass cultivars. HortScience 14:282-283.

Watschke, T.L. 1983. Control of smooth crabgrass in turf using pre- and postemergence herbicides. Proc. Northeast. Weed Sci. Soc. 37:389-390.

\title{
Changes in Guavas of Three Maturity Stages in Response to Temperature and Relative Humidity
}

\author{
Roberto I. Vazquez-Ochoa and Maria T. Colinas-Leon ${ }^{1}$ \\ Departamento de Fitotecnia, Universidad Autonoma Chapingo, \\ Chapingo, Edo. de Mexico, 56230 Mexico
}

Additional index words. Psidium guajava, maturity, firmness, chilling injury

Abstract. Maturity at harvest influenced storage life of guava (Psidium guajava L.) fruit kept at 3.5, 7, or $11 \mathrm{C}$ and $80 \%$ or $88 \%$ RH. Quality characteristics considered were firmness, pH, titratable acidity, ascorbic acid and soluble solids concentrations, and weight loss. Chilling injury was observed only in guavas harvested at the maturegreen stage and kept at 3.5 or $7 \mathrm{C}$. The storage life of fruit kept at $11 \mathrm{C}$ was reduced due to fungal attack. The best results were obtained with guavas harvested at the colorturning stage followed by storage at $7 \mathrm{C}$ and $80 \% \mathrm{RH}$ for 3 weeks. These fruits had good appearance 5 days after removal from storage.

Guavas are highly perishable fruits, with production for the fresh market generally limited to a few weeks. Studies to increase the storage life of these fruits are scarce (Wilson, 1980). Both ethylene absorbers (AhIawat et al,, 1980) and morphactins (Gupta and Mukherjee, 1980) have been tried to slow ripening, without success. High $\mathrm{CO}_{2}$ concentration was also not very effective in increasing storage life (Ahlawat et al., 1978). In general, refrigeration is the preferred and more convenient method (Pantastico, 1975; Ryan and Pentzer, 1974; and Singh and Mathur, 1954) for storage of these climacteric fruits (Akamine and Goo, 1979). The present study was designed to evaluate the effect of temperature and relative humidity on the postharvest storage life of mature guavas harvested at different stages of ripeness.

Guava fruits were obtained from a commercial orchard at Calvillo, Aguascalientes, Mexico. After harvest, they were quickly transported (during the night) to Chapingo, where the experiments were performed. Fruits were picked at the following three stages of ripeness: mature-green (Stage 1), when maximum growth of the fruits had been attained and their skin was dark to light green; turning (Stage II), when the skin was light green to yellow (this is the usual commercial harvest stage); and fully ripe (Stage 111), when the fruits are completely yellow and ready to eat.

Fruits of the same size with no bruising were chosen. After washing with water and weighing, the fruits (15 fruits per treatment, with three replicates) were placed in trays and covered with perforated polyethylene film. Desired humidities were obtained by using saturated solutions of $\left(\mathrm{NH}_{4}\right)_{2} \mathrm{SO}_{4}$ for

Received for publication 16 Feb. 1988. The cost of publishing this paper was defrayed in part by the payment of page charges. Under postal regulations, this paper therefore must be hereby marked advertisement solely to indicate this fact.

'Person to whom reprint requests should be addressed.
$80 \% \mathrm{RH}$ and $\mathrm{KCl}$ for $88 \% \mathrm{RH}$ (Winston and Bates, 1960). Small air pumps were used to circulate the air over the trays. Refrigerated rooms held at 3.5, 7, and $11 \mathrm{C}$ were used. Control fruits, at each temperature, were not covered and were exposed to ambient relative humidity $(55 \%)$. In addition, a general control at ambient temperature $(\approx 20 \mathrm{C})$ was used.

Fruits were analyzed before and after storage. Firmness (as penetration force) was determined on opposite sides of fruit with an Effegi penetrometer fitted with an 8-mm-diameter tip. Soluble solids content (SSC) was determined with a Zeiss (New York) manual refractometer. The $\mathrm{pH}$ was measured on undiluted juice extracted from the fruit at 20C. Titratable acidity was determined by titrating filtered juice samples obtained from $10 \mathrm{~g}$ of material with $0.1 \mathrm{~N} \mathrm{NaOH}$ to an end-point $\mathrm{pH}$ of 8.1 using a $\mathrm{pH}$ meter. Data are expressed as percent of citric acid. Ascorbic acid was determined according to Jacobs (1962) using metaphosphoric acid extraction and 2,6-dichlorophenolindolephenol dye reduction. Weight loss was the difference between the initial weight of each lot and the weight after the storage period, which ranged from 2 to 4 weeks, according to stage of ripeness. After an additional 5 days in air at $20 \mathrm{C}$, subsamples from each storage treatment were visually assessed for general appearance. The experiment was analyzed using a completely randomized factorial analysis.

Mature-green fruits (Stage I) could be stored up to 4 weeks. Fruits stored at $11 \mathrm{C}(80 \%$ and $88 \% \mathrm{RH})$ or at $7 \mathrm{C}(88 \% \mathrm{RH})$ began to show fungal development after 2 weeks. Ripe fruits (Stage HI) had a storage life of 2 weeks; 1 week more than was cited by Ryan and Pentzer (1974) for very ripe guavas. Control fruits at ambient temperature had a very limited storage life. Data shown in Table 1 for these fruits were taken after 4 days of storage, when the fruits already were very soft.

Mature-green fruits stored at 3.5 or 7C, irrespective of the relative humidity showed symptoms of chilling injury $(\mathrm{Cl})$. The symp- 